\title{
СТЕФАН СТАМБОЛОВ В ОЦІНКАХ СУЧАСНОЇ БОЛГАРСЬКОЇ ІСТОРІОГРАФІЇ
}

\author{
Д. В. Миколенко
}

Миколенко Д. В. Стефан Стамболов в оцінках сучасної болгарської історіографії. У представленій статті аналізуються наукові праці сучасних болгарських авторів, присвячені діяльності державника С. Стамболова. Автор розглядає вплив традицій марксистської історіографії, нинішньої політики пам'яті у Болгарії, а також новітньої методології дослідження на висвітлення питань, пов'язаних із міжнародними і внутрішніми ініціативами першого самостійного «стамболовістського» кабінету міністрів. Історик констатує створення вченими у цілому позитивного образу політика, але разом $з$ тим відмічає продовження дискусії навколо деяких аспектів його практик.

Ключові слова: С. Стамболов; Народно-ліберальна партія; «стамболовісти»; сучасна болгарська історіографія; державна політика пам’яті.

Миколенко Д. В. Стефан Стамболов в оценках современной болгарской историографии. В представленной статье анализируются труды современных болгарских авторов, посвященных деятельности государственника С. Стамболова. Автор рассматривает влияние традиций марксисткой историографии, нынешней политики памяти в Болгарии, а также новейшей методологии исследования на освещение вопросов, связанных с международными и внутренними инициативами первого самостоятельного «стамболовистского» кабинета министров. Историк констатирует создание учеными в целом положительного образа политика, но вместе с тем отмечает продолжение дискуссии вокруг некоторых аспектов его практик.

Ключевые слова: С. Стамболов, государственник; Народно-либеральная партия; «стамболовисты»; современная болгарская историография; государственная политика памяти.

Mykolenko D. V. Stefan Stambolov in the Estimates of the Contemporary Bulgarian Historiography. The article analyzes the works of contemporary Bulgarian authors devoted to the activity of the statesman S. Stambolov. The author examines both the traditions of Marxist historiography and the current politics of memory in Bulgaria as well as the latest research methodology and their impact on the manner of illuminating the issues concerning international and domestic initiatives taken by the first «stambolovist's» government. The researcher draws the conclusion that the image of politician created by scientists is quite positive, but at the same time the ongoing discussion about some aspects of his practices is still evolving.

Keywords: S. Stambolov; People's Liberal Party; «stambolovists»; contemporary Bulgarian historiography; politics of memory.

Стефан Ніколов Стамболов (1854-1895 pр.) безумовно є однією з найбільш помітних постатей в історії Болгарії останньої чверті XIX ст. У доленосний для країни період, коли відбувалося становлення державності, він зійшов на політичну авансцену. Це сталося після перевороту 1886 р., організованого проросійськи налаштованими офіцерами болгарської армії, котрі заради налагодження відносин із Санкт-Петербургом вирішили відсторонити від влади князя Алєксандра I Батенберга. С. Стамболов, будучи на той час головою Народних зборів, не підтримав заколотників, а організував контр-переворот з метою відновлення на троні законно обраного монарха. Взявши гору в протистоянні, він протягом 1886-1887 рр. очолював Регентську раду - колегіальний орган здійснення повноважень глави держави, утворений після зречення Батенберга від княжого престолу. Обіймаючи цю посаду, С. Стамболов сприяв приходу на болгарський трон німецького принца Фердинанда Саксен-Кобург-Готського та обмеженню впливу Російської імперії на внутрішні справи князівства. Його принципова позиція щодо взаємин із Санкт-Петербургом, а також небажання останнього йти на компроміси 3 прагненнями Софії призвели до розриву в 1886 р. двосторонніх дипломатичних відносин.

31887 по 1894 р. С. Стамболов очолював уряд країни, поєднуючи виконання посадових обов'язків з членством у заснованій ним в середині 1880-х років Народно-ліберальній партії (НЛП). Реалізовуючи свої владні повноваження, він застосовував авторитарні методи правління. Через це більшість громадськості країни сприймала його як диктатора. 
Зворотною стороною його діяльності стали значні успіхи Болгарії у модернізації економіки та розвитку ринкових відносин. Крім того, Софія домоглася від Порти поступок у вирішенні на свою користь македонсько-одринської проблеми, а всупереч намаганням Росії ізолювати князівство на міжнародній арені С. Стамболову вдалося налагодити контакти 3 Австро-Угорщиною і Великою Британією, заручившись їхньою підтримкою у деяких сферах на міждержавному рівні.

Політична спадщина, що iï залишив після своєї трагічної загибелі 1895 р. С. Стамболов, має суперечливий характер. Зміцнивши інститут монархії та забезпечивши легітимність правлячої династії, він відкрив Фердинанду шлях до встановлення на початку XX ст. режиму особистої влади. Протистояння між угрупованнями русофобів і русофілів, яке розпочалося за часів регентства С. Стамболова, протягом тривалого періоду залишалося найхарактернішою особливістю партійної системи країни та свідченням розколу в суспільстві. Надмірне розширення штату чиновників і поліцейського апарату, характерне для епохи перебування при владі «стамболовістів», стало невід'ємним атрибутом системи адміністративного управління Болгарії. Воно обтяжувало державний бюджет та зрештою спричинило декілька криз в економіці, що їх країна пережила наприкінці XIX - на початку $\mathrm{XX}$ ст. Наслідки ускладнення відносин з Росією, у тому числі й розрив з нею дипломатичних відносин, нагадували про себе і після відновлення у 1896 р. двосторонніх взаємин. Санкт-Петербург обрав собі нового фаворита на Балканах - Сербію та сприяв реалізації зовнішньополітичних амбіцій Белграда.

Російська дореволюційна історіографія ${ }^{1}$ створила однозначно негативний образ політика, діяльність якого призвела до втрати взаємозв'язків із Санкт-Петербургом, а також сприяла встановленню режиму «кривавого терору» в Болгарії. Деякі спроби по-іншому оцінити роль С. Стамболова в історії робилися у Радянському Союзі в 1920-х - 1930-х роках: на тлі різкої критики зовнішньої політики Російської імперії починання болгарського прем'єр-міністра трактувались як прагнення захистити національні інтереси держави². Однак уже під час Другої світової війни зазначена тенденція змінилася попереднім дореволюційним підходом до інтерпретації ініціатив С. Стамболова: у не чисельних публікаці$я^{3}$ радянських авторів із вказаної тематики він знову перетворився на негативного героя - цього разу провідника інтересів Німеччини й Австро-Угорщини на Балканах, типового представника буржуазії, котрий прагнув особистого збагачення за рахунок зловживань владою. Сучасні російські дослідники ${ }^{4}$ переглянули оціночні підходи своїх попередників щодо цілей, пріоритетів, засобів і методів ведення С. Стамболовим зовнішньої і внутрішньої політики. Його діяльність розглядається ними переважно у контексті розбудови національної держави, а також розвитку економіки і соціальної сфери. При цьому частіше підкреслюються саме заслуги регента і прем'єр-міністра у перетворенні Болгарії на модерну європейську країну.

У західній історіографії перші роботи, присвячені вивченню біографії С. Стамболова, 3'явилися ще наприкінці XIX ст. ${ }^{5}$ В них ініціативи політика оцінювались однозначно позитивно. Свою позицію автори аргументували переважно тим, що С. Стамболов сприяв зміцненню незалежності своєї держави, а також ііі переорієнтації на Захід. Подібне визначення притаманне і сучасному американському вченому Д. Перрі, котрий вивчав процеси соціально-економічної і політичної модернізації Болгарії в останній третині XIX ст. В одному із своїх досліджень ${ }^{6}$ він підкреслив вагомий внесок прем'єр-міністра у перетворення відсталої аграрної країни на європейську державу.

А от у болгарській історіографії різні аспекти діяльності С. Стамболова інтерпретувалися неоднозначно. На початку XX ст. з'явилися перші роботи ${ }^{7}$, котрі знов таки, стосуються вивчення біографії відомого державного діяча. Образ С. Стамболова, створений публіцистами й істориками у цей період, вирізняється суперечливістю. Одні характеризують його як національного героя та рятівника країни ${ }^{8}$, інші називають узурпатором, диктатором і русофобом9. Методи впровадження регентом і прем’єр-міністром концептуальних засад державної політики використовувалися в агітаційно-пропагандистських цілях. За часів Народної Республіки Болгарія (НРБ), коли жодної альтернативи дружнім взаєминам із СРСР не існувало, а в науці домінувала марксистська методологія, починання С. Стамболова пов'язувалися з егоїстичними класовими прагненнями промислової і торговельної буржуазії ${ }^{10}$. Незважаючи на те, що упродовж $1960-1980$-х років болгарські вчені 
все частіше виходили за рамки загальноприйнятої тоді версії щодо ролі політика у державотворчих процесах ${ }^{11}$, підкреслюючи його заслуги у національно-визвольних змаганнях, захисті інтересів батьківщини тощо, більшість із них все ж залишалися вірними усталеному в історіографії канону12.

Після «оксамитової революції» 1989-1990рр. інтерес до діяльності С. Стамболова значно зріс. 3 одного буку, це було визначено недостатньою вивченістю окремих аспектів його правління, з іншого - соціально-економічною, політичною і моральною кризами у болгарському суспільстві після зміни режиму, що призвело до необхідності пошуку орієнтирів у минулому, здатних обгрунтувати новий вектор розвитку Болгарії, яка вступила на шлях відродження національної держави та поступової переорієнтації на західні країни. С. Стамболов якнайкраще підходив на роль героя. Про нього почали писати біографічні й документальні романи ${ }^{13}$, котрі пізніше лягли в основу сценаріїв до фільмів, порівнювати 3 видатними державними діячами XIX століття ${ }^{14}$, такими як О. Бісмарк і К. Кавур, його портрет зображено на одній із купюр національної валюти - номіналом у 20 левів, протягом 1990-х років на честь колишнього регента і глави уряду в різних містах і селищах Болгарії названо вулиці й майдани, побудовано пам'ятники*. Хоча жодне 3 офіційних свят країни - дні визволення від османської неволі (3 березня), об'єднання зі Східною Румелією (6 вересня), незалежності від Туреччини (22 вересня) та інші безпосередньо і не пов'язане 3 ім'ям С. Стамболова, проте кожного року з нагоди народження або смерті видатного державника біля місця його поховання й споруджених монументів відбуваються урочисті заходи, неодмінним атрибутом яких $є$ покладання квітів і вінків.

У 1990-х роках в Республіці Болгарія були опубліковані перші збірники документів, котрі безпосередньо стосуються діяльності політика. Так, 1995 року завдяки кропіткій праці історика-юриста Наді Бояджієвої відбулась презентація книги ${ }^{15}$, яка вмістила промови С. Стамболова у Народних зборах. За допомогою цих парламентських виступів можна вивчати еволюцію ідеологічних поглядів засновника НЛП, його ставлення до конкретних політичних процесів. Особливо важливе значення має багатотомне видання ${ }^{16}$ архіву С. Стамболова, укладачами якого стали науковці Мілен Куманов і Дімітр Іванов**. Воно представлене опублікованими у 1997 р. першими п'ятьма томами та іншими п'ятнадцятьма, надрукованими упродовж 2001-2005 років ${ }^{* * *}$, котрі містять безліч різноманітних історичних джерел: епістолярну спадщину державника, стенограми виступів у парламенті, статті тощо. Наданий для широкого загалу матеріал дозволяє сформувати уявлення про політичні судження діяча, особливості його взаємовідносин з іншими представниками болгарського істеблішменту, специфіку внутрішнього і зовнішнього курсів очолюваного ним уряду. В спеціальному альбомі ${ }^{17}$, створеному зусиллями тих же М. Куманова і Д. Іванова, зібрано й упорядковано візуальні джерела, які безпосередньо стосуються життєвих буднів і державотворчих діянь С. Стамболова. Серед них - світлини, гравюри, скановані мапи та інші документи, котрі фундаментально доповнюють багатотомний архів політика.

Таким чином, на зламі 1980-1990-х років значно зріс інтерес болгарських вчених до біографії колишнього глави Регентської ради і уряду. Водночас у зв'язку з тим, що значення і роль С. Стамболова в політиці історичної пам'яті кардинально змінилися, дискурс навколо його діяльності перейшов із суто наукової площини у сферу публічного обговорення та навіть боротьби за владу ${ }^{18}$. Останнє ставало на заваді об'єктивному ставленню громадськості до ідей і практик державника. На загал болгари продовжували неоднозначно сприймати С. Стамболова. Одні визнавали його національним героєм ${ }^{19}$, інші продовжували схилятися до комуністичної версії трактування ініціатив політика ${ }^{20}$. Одностайною залишалася лише теза про суперечливість починань першого лідера НЛП ${ }^{21}$.

Вже згадуваний нами Д. Іванов у своєму нарисі ${ }^{22}$ акцентує увагу на притаманних роботам дослідників часів НРБ неоднозначних крайнощах: 3 одного боку - це герой-рево-

* 1995 року пам’ятники С. Стамболову було зведено в Софії і Велико Тирново, 1998-го - у Пловдиві, 2002-го - в місті Банкя.

** Винятком є перший том, в укладанні якого історик не брав участі.

*** Сімнадцятий і вісімнадцятий томи - це документальні збірники, які було упорядковано відповідно у 1995 і 1996 роках та випущено видавництвами «Отечествен фронт» і «Отечество». 
люціонер, ліберал і демократ; з іншого - націонал-революціонер і буржуазний діяч, котрі проявлялися при розкритті образу С. Стамболова. Автор стверджує: «Характеристика [icториками-марксистами. - Д. М.] правління Стамболова як процесу особистої моральної та інтелектуальної деградації... є ненауковою»²3. «Його діяльність необхідно аналізувати невідривно від конкретних історичних умов» ${ }^{24},-$ наголошує Д. Іванов.

У своїх наступних роботах ${ }^{25}$ він зосередив основну увагу на тих аспектах політики державника, котрі раніше не знаходили достатнього відображення. Автор критикує поширене твердження, що С. Стамболову «...були притаманні нерішучість та різкі зміни у поглядах ${ }^{26}$. На думку дослідника, учасник Старозагорського і Квітневого повстань завжди залишався послідовним і принциповим у своїх діях, а наслідками його політики на посаді голови виконавчого органу став поступ болгарської нації, адже започатковані ним ініціативи сприяли розвитку економіки і культури країни. Одна 3 найбільш дискусійних проблем стосовно авторитарних методів реалізації влади першим самостійним урядом «стамболовістів» також трактувалася по-новому. Наприклад, запроваджені кабінетом міністрів переслідування опонентів під час виборчих процесів, на думку Д. Іванова, завжди мали законне підгрунтя ${ }^{27}$.

Отже, автор намагається спростувати найбільш властиві історіографії НРБ штампи, які застосовувалися для характеристики політики С. Стамболова. При цьому твердження Д. Іванова, з нашої точки зору, недостатньо аргументовані, оскільки він не залучив нові, до того ще не застосовані джерела для доводу власної правоти.

Проблем, пов'язаних з діяльністю політика, торкнувся також Енчо Матеєв ${ }^{28} .3$ приводу зовнішньополітичної орієнтації голови Регентської ради дослідник зазначає: «Стамболов ніколи не ставив під сумнів заслуги Росії у визволенні Болгарії, а пішов проти волі Санкт-Петербурга тому, що цього вимагали державні інтереси країни. У 1886 р. князівство стояло перед вибором: або іти шляхом незалежності й свободи, або перетворитися на підвладну територію. Обравши перше, Стамболов вчинив правильно» ${ }^{29}$. Розмірковуючи над наслідками правління регента і прем'єр-міністра для подальшого розвитку держави, Е. Матеєв намагається виправдати його за те, що привів на болгарський престол Кобурга: «Для Стамболова і Батенберг, і Фердинанд не мали ніякого значення як особистості, а були лише персоналізацією конкретного інституту, котрий став символом незалежності країни». При цьому автор стверджує про наявність у політика негативних рис: «Недостатні інтелектуальна зрілість та сила характеру завадили втіленню в життя великих перспектив Третьої держави» ${ }^{30}$.

Втім далеко не всі історики, котрі працювали у Болгарії наприкінці 1980-х - на початку 1990-х років, підтримували зміни в країні та погодилися з новими трендами політики пам'яті. Дехто із публіцистів і науковців продовжував оцінювати діяльність С. Стамболова, застосовуючи попередні методологічні підходи. Так, Страшимир Пеневскі називає державника диктатором, котрий дбав виключно про власні інтереси та «залишив жахливі й огидні спомини про власне восьмирічне правління» ${ }^{31}$.

Професор історії Іскра Баєва, яка нині представляє створену 1990 р. колишніми комуністами доволі впливову і на сьогоднішній день в країні Болгарську соціалістичну партію, в одній із робіт ${ }^{32}$ не ставить під сумнів політичний талант, а також заслуги С. Стамболова у забезпеченні незалежного від Росії зовнішнього курсу Софії. Але разом з тим вона критикує його за диктаторські методи управління та різке протиставлення князівства великим державам, що мало негативні наслідки для держави.

Один із лідерів іншої політичної сили лівого спрямування - Соціалістичної партії «Болгарський шлях», котра послідовно демонструє яскраво виражену орієнтацію на Москву, професор економіки Ангел Дімов написав книгу «Злодіяння Кобургів у Болгарії» ${ }^{33}$. У цій роботі С. Стамболов постає у негативному образі. Автор акцентує увагу на його індивідуальних рисах політика - властолюбстві, надмірній пристрасті до азартних ігор, недовірливості, а також критикує за корупційні схеми, що існували у період його прем'єрства ${ }^{34}$. Найбільшою помилкою С. Стамболова вчений вважає запрошення на болгарський престол німецького принца Фердинанда, чиє перебування при владі обернулося для країни двома національними катастрофами.

Починаючи з середини 1990-х років, у болгарській історичній науці почали домінувати інші судження відносно С. Стамболова. 1994 року в Софії і Велико Тирново відбулися 
масштабні конференції, приурочені 140-річчю від дня народження державного діяча. Вони стали важливою віхою у переосмисленні діяльності цього видатного політика. Тогочасний президент Болгарської Республіки Ж. Желев у вступній промові на пленарному засіданні в столиці назвав С. Стамболова одним із засновників ліберального руху в країні, а представник партії «Політичний клуб “Конституційний форум”» Н. Генчев - державником, котрий заклав підвалини новітньої Болгарії. На вказаних конференціях були представлені доповіді, присвячені участі С. Стамболова у національно-визвольному русі та діяльності на посаді регента і прем'єр-міністра, а також озвучені матеріали із особистого архіву політика, що проливають світло на генеалогію його роду. Матеріали обох наукових форумів наступного року були опубліковані одним збірником ${ }^{35}$ під редакцією вже згадуваного нами Д. Іванова.

У порівнянні зі своїми надрукованими у період існування НРБ працями ${ }^{36}$, історик Андрей Пантев після 1990 р. суттєво скорегував власні оцінки щодо ініціатив С. Стамболова. «Політик, - констатує автор у черговій роботі, - сприяв внутрішній стабілізації режиму, господарчій модернізації, національній консолідації, а згодом повернув країну в лоно ефективної демократії» ${ }^{37}$.

А. Пантев підкреслює досягнення прем’єра у посиленні впливу Екзархату на територію європейських вілаєтів Османської імперії - Македонії і Фракії, а саме призначення болгарських владик у кількох єпархіях, розташованих у вказаних областях, а також загалом добросусідські відносини між Софією і Стамбулом, що встановилися завдяки зусиллям лідера «стамболовістів». На підставі наявності вказаних успіхів дослідник робить сміливе і не характерне для істориків припущення: «Для [Стамболова - Д. М.] не склало б труднощів уникнути помилок 1913 і 1915 років, [очевидно, пов'язаних з втратою Софією більшої частини македонських земель - Д. М.]» ${ }^{38}$. Таким чином, автор вважає політику болгарського регента і прем'єра щодо реалізації проекту національного об'єднання найбільш прийнятною для країни, а відхід від неї у 1910-х роках називає основною причиною краху сповідань на реалізацію зазначеної мети.

Вчений виправдовує як жорсткий авторитарний режим, встановлений прем'єрміністром, так і його кроки на міжнародній арені ${ }^{39}$. Займаючи активну громадську позицію, А. Пантев неодноразово переносив заходи С. Стамболова на болгарську політичну дійсність початку XXI ст. У чисельних інтерв'ю і публіцистиці історика засновник НЛП постає взірцем для нинішнього і майбутнього поколінь істеблішменту країни ${ }^{40}$.

Відомий науковець Радослав Попов на основі широкої джерельної бази розглядає болгарсько-російські взаємини періоду регентства і прем'єрства С. Стамболова у 18861894 рр., враховуючи при цьому загальну картину міжнародних відносин в Свропі. Автор звертає увагу не лише на досягнення, а й на прорахунки офіційної Софії. Серед останніх називаються безрезультатні переговори із Санкт-Петербургом у 1888 i 1891 роках з приводу відновлення двосторонніх дипломатичних зв'язків ${ }^{41}$.

Безумовною заслугою істориків, які професійно відбулися за часів НРБ та наприкінці 1980-х - упродовж першої половини 1990-х років продовжували працювати над вивченням діяльності С. Стамболова, $€$ те, що вони у більшості своїй зуміли переглянути власні судження, а в деяких випадках визнати помилки. Поступово вчені почали залучати нові, нехарактерні для науки комуністичного періоду, методологічні прийоми, наприклад, розглядати особистісну специфіку С. Стамболова, особливості його характеру як фактори, котрі визначали політичні кроки державника на посаді регента і прем’єр-міністра. Завдяки залученню все нових і нових джерел дослідники стали глибше розуміти і ширше трактувати умови, в яких визрівали ідеї і практики засновника НЛП.

Генерація професійних істориків, котра сформувалася упродовж 1980-х - 1990-х років, визнала за С. Стамболовим заслуги у зміцненні боєздатності армії ${ }^{42}$, модернізації економіки й соціальної і культурної сфери ${ }^{43}$, вирішення македонського питання ${ }^{44}$. Але найбільш суперечливими, як і раніше, залишалися його міжнародна орієнтація та методи реалізації влади. Мілко Палангурскі у двох монографіях і деяких статтях детально розглянув одну із основних складових політичної системи країни - виборчі процеси ${ }^{45}$. Він звертає увагу на чисельні, відпрацьовані у період прем'єрства С. Стамболова, усталені практики і механізми, які дозволяли забезпечувати бажаний результат волевиявлення населення та настільки міцно закріпилися, що нагадували про себе упродовж тривалого часу після від- 
ставки голови уряду ${ }^{46}$. У цілому М. Палангурскі високо оцінює заслуги державника перед батьківщиною, зазначивши в одному з інтерв'ю, що С. Стамболов $є$ фактично «...єдиною постаттю Болгарії періоду становлення державності» і саме йому, з точки зору дослідника, належить авторство концепції зовнішнього-політичного курсу країни, якому вона слідує й понині ${ }^{47}$.

Серед найбільш важливих питань діяльності регента і прем'єр-міністра у 18861894 pp., які можуть суттєво вплинути на загальну оцінку його заходів та дотепер не знайшли достатнього висвітлення в роботах сучасних болгарських істориків, залишається політична спадщина С. Стамболова. Свого часу це поняття ввів до наукового обігу А. Пантев $^{48}$, однак 3 тих пір не було презентовано жодної спеціальної роботи, котра б стосувалася вказаної проблеми. Єдиною площиною, в якій хоча й частково, та все ж проводилися дослідження цього питання, стало вивчення подальшого функціонування Народно-ліберальної партії, котра після смерті свого засновника продовжувала залишатися однією 3 провідних політичних сил країни та основним хранителем і ретранслятором спадщини С. Стамболова. Великий внесок у розкриття зазначеної проблеми зробив відомий історик Дімітр Саздов. У деяких своїх статтях ${ }^{49}$ він відобразив ставлення «стамболовістів» до відновлення у 1896 р. дипломатичних зв'язків з Росією, а також стратегію і тактику членів НЛП у боротьбі за повернення до влади, їхні взаємовідносини з монархом тощо.

Таким чином, упродовж 1990-х - 2010-х років у Болгарії було опубліковано значну кількість наукової літератури, яка стосується державотворчих ініціатив С. Стамболова на посаді голови Регентської ради і кабінету міністрів. Аналіз цих публікацій виявив спробу деяких авторів відродити те, що свого часу французький вчений П'єр Нора назвав національним романом, а також стійку тенденцію, направлену на реабілітацію Стамболова як одного із героїв подібних робіт та створення його позитивного образу. 3 іншого боку, частина дослідників і надалі вважає більш доречною, а тому й популяризувала створену ще за часів Третього болгарського царства «народняком» ${ }^{*}$ М. Маджаровим та підтриману істориками НРБ версію про негативні для держави наслідки правління першого самостійного уряду «стамболовістів». Отже, можна констатувати, що в академічному середовищі істориків Болгарії продовжуються дискусії навколо деяких аспектів діяльності Регентської ради і уряду на чолі зі С. Стамболовим, наприклад, зовнішнього курсу, а також методів реалізації влади. Наявність сьогодні іноді протилежних думок щодо ролі колишнього регента і прем'єр-міністра у болгарському державотворенні зумовлена політизованістю представленої теми та пропагуванням партіями країни різних варіантів державної політики історичної пам'яті. Проте існування широкого кола дискусійних питань, пов'язаних із зазначеною проблематикою, залишає поле для досліджень сучасних науковців. На нашу думку, глибоке вивчення такого феномену, як політична спадщина С. Стамболова, котра визначала розвиток країни і після його відставки й загибелі, здатне суттєво скорегувати уявлення про місце і значення видатного державника в історії Болгарії.

${ }^{1}$ Матвеев П. А. Болгария после Берлинского конгресса: Исторический очерк. - СПб.: Типография В.С. Балашев и Кㅇ $1887 .-345$ с.; Овсяный Н. Р. Болгария и болгары. - СПб.: Военная типография, 1900. - 365 с.; Погодин А. Л. История Болгарии. - СПб.: Брокгауз-Ефрон, 1910. - 224 с; Ястребов Н. В. История болгарского народа / Н. В. Ястребов, П. А. Лавров. - Петроград: Типо-литография И. Юделевич, 1916. - 544 с.

${ }^{2}$ Севериев П. Царская дипломатия на Балканах (Из воспоминаний) // Международная жизнь. - Москва; Петроград, 1923. - № 1. - С. 148-160; Гримм Э. Д. К истории русско-болгарских отношений // Новый Восток. - 1924. - Кн. 5. - С. 68-85; Сидельников С. И. Авантюра русского царизма в Болгарии (1878-1896 гг.) // Ученые записки Ленинградского государственного университета: Серия история. - 1939. - Т. 36. - Вып. 3. - С. 145-180.

${ }^{3}$ История Болгарии / Под ред. П. Н. Третьякова, С. А. Никитина. - М.: Академия наук СССР, 1954. - Т. 1. - 576 с.; Киняпина Н. Болгария в балканской политике России (1886-1896 гг.) // Отечественная история. - 1992. - № 2. - С. 43-55.

* «Народняки» - члени Народної партії, однієї з найбільш впливових політичних сил наприкінці $\mathrm{XIX}$ - на початку XX ст. Заснована 1894 р. після падіння режиму С. Стамболова колишніми консерваторами князівства, південно-болгарськими «з'єдністами» та деякими членами інших угруповань. 
${ }^{4}$ Косик В. Размышления о судьбах Болгарии, Стефана Стамболова, государственности // Человек на Балканах. Государство и его институты: гримасы политической модернизации (последняя четверть XIX - начало XX вв.). - СПб.: Алетейя, 2006. - С. 117-124; Гришина Р. Лики модернизации в Болгарии (бег трусцой по пересечённой местности). - М.: Институт славяноведения РАН, 2008. - 256 с.

${ }_{5}^{5}$ Биман А. Стамболов: Биография. - С.: Наука и изкуство, 1990. - 220 с.

${ }^{6}$ Perry D. Stefan Stambolov and the Emergence of Modern Bulgaria, 1870-1895. - Durham: Duke University Press, 1993. - 279 p.

${ }^{7}$ Радев С. Строителите на съвременна България: Царуването на кн. Александра 1879-1886. С.: Т. Пеев, 1910. - Т. 1. - 835 с.; Його ж. Строителите на съвременна България : Регентството. - С.: П. Глушков, 1911. - Т. 2. - 835 с.

8 Генадиев П. Стефан Стамболов: Исторически случаи от живота на български политически дейци. - С.: Университетско изд-во «Св. Климент Охридски», 1991. - 165 с.

${ }^{9}$ Маджаров М. От самовластие към свобода и законност. - С.: Мир, 1936. - 81 с.

${ }^{10}$ Йоцов Я. Класи и партии у нас до 1923 година // Исторически преглед. - 1947. - № 2. - С. $177-$ 193; Христов X. Към характеристиката на Стамболовия режим // Исторически преглед. - 1951. - № 1 . - C. $19-49$.

11 Дечев $C$. Нежеланият Стамболов: Раждането на новата интерпретация за Стамболов и стамболовизма в българската историография в края на 40-те и началото на 50-те години на XX век // Анамнеза. - 2008. - № 2. - С. 3-84.

12 Пантев А. Англия и България в европейската криза през 1887 г. // Известия на Българското историческо дружество. - 1972. - Т. 28. - С. 91-116; Стателова Е. Политика, партии, печат на българската буржоазия 1909-1912. - С.: Наука и изкуство, 1973. - 186 с.; Танкова В. Проблеми на организационното устройство и развитие на Народнолибералната партия (1886-1894) // Векове. - 1988. - № 5. - С. 21-30.; Ï̈ ж. Формиране на Народно-либералната (стамболовистка) партия в Пловдив (1887-1894) // Известия на музеите от Южна България. - Пловдив, 1989. - Т. 15. - С. $299-317$.

${ }^{13}$ Терзиев К. Стефан Стамболов. - С.: Български писател, 1993. - 368 с.; Даскалов Х. След игото: Стефан Стамболов. - С.: ФУМИ Прес, 1994. - 136 с.; Иванов Н. Избраникът: Исторически роман. Велико Търново: Абагар, 1994. - 172 с.; Його ж. Последните дни на Стефан Стамболов. - С.: Родина, 1995. $-64 \mathrm{c}$.

${ }^{14}$ Петков 3. За нашето героично минало // Всяка неделя. - 1993. - № 35. - С. 16-19; Його ж. Бисмарк на Балканите [Стефан Стамболов] // Новини плюс. - 1995. - № 14. - С. 14, 19.

15 Стефан Стамболов пред Народно събрание: Избрани речи / Съст. Н. Бояджиева. - София, 1995. - $146 \mathrm{c}$.

${ }^{16}$ Стефан Стамболов: Личен архив (писма, телеграми, записки и дневници) / Съст.: М. Куманов. - С.: Отечество, 1997. - Т. 1. - 623 с.; Стефан Стамболов: Личен архив (писма, телеграми, записки и дневници) / Съст.: М. Куманов, Д. Иванов. - С.: Отечество, 1997. - Т. 2. - 430 с.; Стефан Стамболов: Личен архив (писма, телеграми, рапорти 1890) / Съст.: М. Куманов, Д. Иванов. - С.: Отечество, 1997. - Т. 3. - 687 с.; Стефан Стамболов: Личен архив (писма, телеграми, рапорти, записки 1891) / Съст. : М. Куманов, Д. Иванов. - С.: Отечество, 1997. - Т. 4. - 574 с.; Стефан Стамболов: Личен архив (писма, телеграми, записки, доклади, дневници) / Съст.: М. Куманов, Д. Иванов. - С.: Отечество, 1997. - Т. 5. - 447 с.; Стефан Стамболов: Личен архив (писма, телеграми, рапорти, записки) / Съст.: М. Куманов, Д. Иванов. - С.: Университетско изд-во «Св. Климент Охридски», 2001. - Т. 6. - 920 с.; Стефан Стамболов: Личен архив (писма, телеграми, записки, доклади, дневници) / Съст.: М. Куманов, Д. Иванов. - С.: Университетско изд-во «Св. Климент Охридски», 2001. - Т. 7. - 913 с.; Стефан Стамболов: Личен архив (писма, телеграми, записки, доклади, дневници) / Съст. : М. Куманов, Д. Иванов. - С.: Университетско изд-во «Св. Климент Охридски», 2002. - Т. 8. - 847 с.; Стефан Стамболов: Личен архив (писма, телеграми 19. V. 1894 - 5. VII. 1895) / Съст. : М. Куманов, Д. Иванов. - С.: Университетско изд-во «Св. Климент Охридски», 2002. - Т. 9. - 723 с.; Стефан Стамболов: Личен архив (писма, телеграми, бележки) / Съст.: М. Куманов, Д. Иванов. - С.: Университетско изд-во «Св. Климент Охридски», 2001. - Т. 10. - 819 с.; Стефан Стамболов: Личен архив (писма, телеграми, записки, доклади) / Съст.: М. Куманов, Д. Иванов. - С.: Университетско изд-во «Св. Климент Охридски», 2002. - Т. 11. - 681 с.; Стефан Стамболов: Личен архив (писма, телеграми, записки 1888) / Съст.: М. Куманов, Д. Иванов. - С.: Университетско изд-во «Св. Климент Охридски», 2003. - Т. 12. - 707 с.; Стефан Стамболов: Личен архив (писма, телеграми, записки, доклади, дневници) / Съст. : М. Куманов, Д. Иванов. - С.: Университетско изд-во «Св. Климент Охридски», 2003. - Т. 13. - 414 с.; Стефан Стамболов: Личен архив (писма, телеграми, рапорти, бележки 1890) / Съст.: М. Куманов, Д. Иванов. - С.: Университетско изд-во «Св. Климент Охридски», 2003. - Т. 14. - 573 с.; Стефан Стамболов: Личен архив (писма, телеграми, записки, доклади, дневници) / Съст.: М. Куманов, Д. Иванов. - С.: Университетско изд-во «Св. Климент Охридски», 2003. - Т. 15. - 995 с.; Стефан Стамболов: Личен архив (писма, телеграми, рапорти, записки) / Съст.: М. Куманов, Д. Иванов. - С.: Университетско изд-во «Св. Климент Охридски», 2003. - Т. 16. - 827 с.; Стефан Стамболов: Парламентарни речи: 1879-1894 / Съст.: М. Куманов, Д. Иванов. - С.: Университетско изд-во «Св. Климент Охридски», 1995. - Т. 17. - 550 с.; Стефан Стамболов: Публицистика1875-1895/ Съст.: М. Куманов, 
Д. Иванов. - С.: Университетско изд-во «Св. Климент Охридски», 1996. - Т. 18. - 570 с.; Стефан Стамболов: Биографии / Съст.: М. Куманов, Д. Иванов. - С.: Университетско изд-во «Св. Климент Охридски», 2005. - Т. 19. - 1167 с.; Стефан Стамболов: Биографии / Съст.: М. Куманов, Д. Иванов. С.: Университетско изд-во «Св. Климент Охридски», 2005. - Т. 20. - 980 с.

${ }^{17}$ Стефан Стамболов: албум / Съст. М. Куманов, ред. Д. Иванов. - С.: Университетско изд-во «Св. Климент Охридски», 2005. - 333 с.

${ }^{18}$ Генчев Н. Докато България чака нов Стамболов: Доган командва правителство и парламент: интервю // Дума. - 1993. - № 135. - С. 9; Петров С. Костов откъсна сегмент от ореола на Стамболов // Труд. - 1995. - № 128. - С. 10, 11; Георгиева К. Кого сънува Иван Костов: на бившия премиер му допадна сравнението със Стамболов заради силната воля на неговия предшественик // Монитор. 2002. - № 1217. - С. 1, 11.

${ }^{19}$ Радев С. Делото на Стамболов през погледа на новото време // Земя. - 1994. - № 68. - С. 5; Радев T. Щит и знаме на България: 97 г. от убийството на Стефан Стамболов // Македония. - 1992. - № 29. - С. 1, 6; Його ж. Държавникът, който носеше сърце на поет, но беше човек на дълга: 100 г. от гибелта на Стефан Стамболов // Демокрация. - 1995. - № 153. - С. 6; Його ж. Достойнството на българина стои над всичко: непубликувани истини за семейството на Стефан Стамболов // Пари. 1998. - № 121. - С. 10; Радков Р. Живков беше най-големият след Стамболов // Народен глас. - Ловеч, 2005. - № 65. - C. 3 .

${ }^{20}$ Грънчаров С. Русофилските политически партии, организации и управления в България (август 1886 - август 1887 г.) // Политически партии, организации и управления в България: 18791944 г. - С.: Изд-во на БАН, 1983. - С. 121-150.

${ }^{21}$ Петрова М. Възвеличаваният и поругаваният: 144 г. от рождението на Стефан Стамболов // Про \& Анти. - 1997. - № 4. - С. 8; Петров 3. Колоритна, амбициозна, противоречива личност: Стефан Стамболов - познатият и непознатият // Вечерни новини. - 1993. - № 75. - С. 3; Петров П. Преди и след Стамболов // Българска армия. - 1995. - № 13754. - С. 3.

${ }^{22}$ Иванов Д. Стефан Стамболов: Историко-публицистичен очерк. - С.: Университетско изд-во «Св. Климент Охридски», 1990. - 163 с.

23 Там само. - C. 9.

${ }^{24}$ Там само. - С. 10.

${ }^{25}$ Иванов Д. Стефан Стамболов - българската енергия. - С.: Арес Прес, 1993. - 222 с.; Його ж. Мъжка орис: Стефан Стамболов - българската енергия. Противопоставянето. Български образи. С.: 3. Стоянов, 2001. - 539 с.; Його ж. Стефан Стамболов - от перото до ятагана. - С.: Книгоиздателска къща «Труд», 2005. - 191 с.

27 Иванов Д. Мъжка орис: Стефан Стамболов - българската енергия. Противопоставянето. Български образи. - С.: З. Стоянов, 2001. - С. 197.

${ }^{27}$ Там само. - С. 206.

${ }^{28}$ Матеев Е. Държавникът Стефан Стамболов. - С.: Летописи, 1992. - 224 с.

${ }^{29}$ Там само. - С. 42.

30 Там само. - С. 65.

31 Пеневски С. Кой бяхте вие, Стамболов: През погледа на съвременниците. - С.: СамИздат, 1992. - С. 34

${ }^{32}$ Баева И. Основни тенденции във външната политика на модерната българска държава. - URL: https:/www.google.com.ua/url?sa=t\&rct=j\&q=\&esrc=s\&source=web\&cd=1\&cad=rja\&uact=8\&ved=0 ahUKEwiMx_iN28XMAhVDiiwKHfeCBegQFggcMAA\&url=http\%3A\%2F\%2Fbdi.mfa.government. bg $\% 2$ Finfo $\%$ FModule $\% 252001 \% 2520-\% 2520$ Institucionalna $\% 2520$ ramka $\% 2520$ na $\% 2520$ vanshnata $\% 2$ 520politika\%2FIskra\%2520Baeva\%2520-\%2520Vanshna\%2520politika.doc\&usg=AFQjCNFRi4rtsy5pl6 MJU8r18jU4EUYP2Q\&bvm=bv.121421273,d.bGg (дата звернення: 07.08.2016).

33 Димов А. Злодеяния на Кобургите в България. - С.: Български аграрен съюз, 2005. - 108 с.

${ }^{34}$ Там само. - С. 68.

${ }^{35}$ Стамболов и България: Сборник доклади и съобщения, изнесени на научните конференции в София и Велико Търново по случай 140 години от рождението на Стефан Стамболов / Ред. Д. Иванов. - С.: Арес Прес, 1995. - 164 с.

36 Пантев А. Англия, Германия и българският въпрос (август 1887 - март 1890) // Българогермански отношения и връзки: Изследвания и материали. - София, 1972. - Т. 1. - С. 106-107; Його ж. Англия и България в европейската криза през 1887 г. // Известия на Българското историческо дружество. - 1972. - Т. 28. - С. 91-116; Його ж. Англия срещу Русия на Балканите (1879-1894). - С.: Наука и изкуство, $1972 .-308$ с.

${ }^{37}$ Пантев А. За Стефан Стамболов в часа на България. - С.: Едем 21, 1995. - 206 с.

${ }^{38}$ Там само.

39 Патнев А. Чрез турско-българската държава Стамболов е искал да запази целостта на българския етнос: интервю // Труд. - 1992. - № 286. - С. 1; Його ж. Стратегическата стойкост на България в коалициите на Великите сили (1881-1897) // Модерна България. - С.: Университетско изд-во «Св. Климент Охридски», 1996. - С. 41-62. 
40 Пантев А. Отново и още за Стамболов // АБВ. - 1992. - № 7. - С. 3; Його ж. Още едно завръщане на Стамболов // Български журналист. - 1993. - № 8. - С. 49-50; Його ж. Стамболов е достатъчно ярък, за да го спропираме: интервю // Отечествен вестник. - 1994. - № 14427. - С. 12; Його ж. Хроника на едно презизвеснето убийство: 100 г. от смъртта на Стефан Стамболов // Стандарт news. - 1995. - № 1008. - C. 12-13; Його ж. От Левски до Стамболов: 122 г. от обесването на Апостола // Литературен форум. - 1995. - № 7. - С. 1; Його ж. Последното пророчество на Стефан Стамболов // Литературен форум. - 1995. - № 27. - С. 1, 6; Його ж. Стамболов - съвременникът от миналия век: 145 г. от рождението му // Земя. - 1999. - № 21. - С. 3; Його ж. Костов, не се вжевявай те, че сте Стамболов! // Земя. - 2000. - № 181. - С. 8; Його ж. Стефан Стамболов пред прага на нова забрава // Новинар. - 2000. - № 156. - С. 8; Його ж. Стамболов е една от опорите срещу националното ни обезличаване // Монитор. - 2001. - № 712. - С. 18.

${ }^{41}$ Попов Р. Русия против Стамболов или Стамболов против Русия? - С.: Академично изд-во «роф. Марин Дринов», 2000. - С. 78.

42 Петров Т. Начало на модернизацията в българската армия (1886-1903 г.) // Военноисторически сборник. - 2004. - Кн. 4. - С. 19-22.

${ }^{43}$ Радев И. Моят Стефан Стамболов. - Велико Търново: ПИК, 1999. - 207 с.

${ }^{44}$ Цветков Ж. Сблъсъкът: Фердинанд, Стамболов, Русия (1886-1896). - С.: Университетско издво «Св. Климент Охридски», 2003. - 248 с.

45 Палангурски М. Държавно-политическата система на България (1879-1919). - Велико Търново: Слово, 1995. - 150 с.; Його ж. Избирателната система в България (1879-1911 г.). - Велико Търново: Университетско изд-во «Св. св. Кирил и Методий», 2007. - 271 с.; Його ж. Избори по стамболовистки (1887-1894 г.). - Велико Търново: Университетско изд-во «Св. св. Кирил и Методий», 2008. - 280 с.; Його ж. Подготовка, провеждане и утвърждаване на изборите на VII OHC през 1893 г. // България, българите и Европа. - Велико Търново, 2008. - Т. 2. - С. 115-143.

${ }^{46}$ Палангурски М. Избирателната система в България (1879-1911 г.). - Велико Търново: Университетско изд-во «Св. св. Кирил и Методий», 2007. - С. 142.

47 Палангурски M. Стамболов даде геостратегическата посока на България. - URL: http:/ dariknews.bg/view_article.php?article id=1211040 (дата звернення: 07.08.2016).

48 Пантев А. Противоречивото наследство на Стефан Стамболов // Векове. - 1981. - № 5. C. 69-77.

49 Саздов Д. Буржуазная оппозиция и восстановление отношений между Болгарией и Россией в 1896 году // Bulgarian Historical Review. - 1983. - № 4. - Р. 39-60; Його ж. Българските буржоазни партии, кризата в монархическата институция и възстановяването на руско-българските отношения (1887-1896) // Модерния историк: Въображение, информираност, поколения. - С.: Д. Убенова, 1999. - C. 114-121. 